\title{
Parametric CAD Model of a Double-Lay Six Strand Wire Rope
}

\author{
Michal Fabian ${ }^{1}$, Eva Stanová ${ }^{2}$, Gabriel Fedorko ${ }^{3}$, Stanislav Kmet² ${ }^{2}$ Jana Fabianová ${ }^{3}$, Jozef Krajňák ${ }^{1}$ \\ ${ }^{1}$ Faculty of Mechanical Engineering, Technical University of Košice, Letná 9, Košice, 040 01, Slovakia, E-mail: mi- \\ chal.fabian@tuke.sk, jozef.krajnak@tuke.sk \\ ${ }^{2}$ Faculty of Civil Engineering, Technical University of Kosice, Vysokoškolská 4, 04200 Košice, Slovakia, E-mail: \\ eva.stanova@tuke.sk, stanislav.kmet@tuke.sk \\ ${ }^{3}$ Technical University of Košice, Park Komenského 14, Košice, 040 01, Slovakia, E-mail: gabriel.fedorko@tuke.sk, \\ jana.fabianova@tuke.sk
}

Parametric modelling based on mathematical relationships allows creation of different variants of proposed solutions in real time. In particular, parametric modelling enables rapid design of 3D virtual models intended for further analysis and simulations. This paper presents an approach to design of a six strand wire rope model in a CAD environment. The presented model is characterized by double helical winding wires. Wires axes curves are mathematically expressed in the form of parametric equations. The parametric equations used in model generation are presented and the whole methodology of rope model creation in CATIA V5 software is briefly described.

Keywords: Parametric modelling, wire rope, CAD

\section{Acknowledgements}

This work is a part of research projects VEGA No. 1/0063/16 and 1/0198/15, partially founded by the Scientific Grant Agency of the Ministry of Education of Slovak Republic and the Slovak Academy of Sciences. The present research has been carried out within the project APVV SK-CZ-2013-01691/0401/08.

\section{References}

[1] STANOVA, E., FEDORKO, G., FABIAN, M., KMET, S. (2011). Computer modelling of wire strands and ropes Part I: Theory and computer implementation In:Advances in Engineering Software, Vol. 42, No. 6, pp. 305-315. ISSN 09659978.

[2] SONG, J., CAO, G., CAO, Y., WU, R. (2012). Modeling method and analysis of geometric characteristic for the triangular strand rope. In: Modern Manufacturing Engineering. Vol. 11, pp. 1-7.

[3] GHOREISHI, S., CARTRAUD, P., DAVIES, P., MESSAGER, T. (2007). Analytical modeling of synthetic fiber ropes subjected to axial loads. Part I: A new continuum model for multilayered fibrous structures. In: International Journal of Solids and Structurest. Vol. 44, No. 9, pp. 2924-2942.

[4] GHOREISHI, S., CARTRAUD, P., DAVIES, P., MESSAGER, T. (2007). Analytical modeling of synthetic fiber ropes. Part II: A linear elastic model for $1+6$ fibrous structures. In: International Journal of Solids and Structurest. Vol. 44, No. 9, pp. 2943-2960. ISSN 00207683.

[5] USABIAGA, H., PAGALDAY, J. M. (2008). Analytical procedure for modelling recursively and wire by wire stranded ropes subjected to traction and torsion loads. In: International Journal of Solids and Structures. Vol. 45, No. 21, pp. 5503-5520. ISSN 00207683.

[6] WANG, X., MENG, X., WANG, J., SUN, Y., GAO, K. (2015). Mathematical modeling and geometric analysis for wire rope strands. In: Applied Mathematical Modelling. Vol. 39, No. 3-4, pp. 1019-1032. ISSN 0307904X.

[7] XIANG, L., WANG, H.Y., CHEN, Y., GUAN, Y.J., WANG, Y.L., DAI, L L. (2015). Modeling of multi-strand wire ropes subjected to axial tension and torsion loads. In: International Journal of Solids and Structures. Vol. 58, pp. 233-246. ISSN 00207683.

[8] BÍLEK, O., ROKYTA, L., ŠIMONÍK, J. (2012). CAM in the Production of Casting Patterns. In: Manufacturing Technology. Vol. 12, No. 12. pp. 7 - 12. ISSN 12132489

[9] ARDELEAN, F. A. (2007). 3D Modelling of the harmonic drive using CATIA. In: Management. Vol. IV, No. Xvi, pp. 882-885. 
[10] DU, B., WANG, X., FENG, Y., YU, D., XU, G. (2014). Intelligent assembly technology based on standard parts feature of CATIA. In: Modern Applied Science. Vol. 8, No. 2, pp. 49-55. ISSN 19131844.

[11] SARIC, I., REPCIC, N., MUMINOVIC, A. (2009). 3D Geometric parameter modelling of belt transmissions and transmissions gear. In: TECH TECHNOL EDUC MANAG-TTEM - Technics Technologies Education Management-ttem. Vol. 4, No. 2, pp. 181-188. ISSN 1840-1503.

[12] SKARKA,W. (2007). Application of MOKA methodology in generative model creation using CATIA. In: Engineering Applications of Artificial Intelligence. Vol. 20, No. 5, pp. 677-690. ISSN 09521976.

[13] WANG, D., ZHANG, D., WANG, S., GE, S. (2013). Finite element analysis of hoisting rope and fretting wear evolution and fatigue life estimation of steel wires. In: Engineering Failure Analysis. Vol. 27, pp. 173-193. ISSN 13506307.

[14] ERDÖNMEZ, C., IMRAK, E. (2011). A finite element model for independent wire rope core. In: Sadhana. Vol. 36, No. 6, pp. 995-1008.

[15] A. NAWROCKI, A., LABROSSE, M. (2000). A finite element model for simple straight wire rope strands. In: Computers \& Structures. Vol. 77, No. 4, pp. 345-359. ISSN 00457949.

[16] JIANG, W.G., HENSHALL, J.L., WALTON, J.M. (2000). A concise finite element model for three-layered straight wire rope strand. In: International Journal of Mechanical Sciences. Vol. 42, No. 1, pp. 63-86. ISSN 00207403.

[17] KASTRATOVIĆ, G. M., VIDANOVIĆ, N. D. (2011). Some aspects of 3D finite element modeling of independent wire rope core. In: FME Transactions. Vol. 39, No. 1, pp. 37-40. ISSN 14512092.

[18] KASTRATOVIĆ, G., VIDANOVIĆ, N., BAKIĆ, V., RAŠUO, B. (2009). On finite element analysis of sling wire rope subjected to axial loading. In: Ocean Engineering. Vol. 88, pp. 480-487. ISSN 00298018.

[19] FONTANARI, V., MONELLI, B. D., DEGASPERI, F. (2009). Experimental and numerical analysis of full-locked coil ropes fire behaviour. In: Society for Experimental Mechanics - SEM Annual Conference and Exposition on Experimental and Applied Mechanics. Vol. 2. pp. 1383-1392. ISBN 9781615671892.

[20] WANG, D. ZHANG, D., ZHANG, Z., GE, S. (2012). Effect of various kinematic parameters of mine hoist on fretting parameters of hoisting rope and a new fretting fatigue test apparatus of steel wires. In: Engineering Failure Analysis. Vol. 22, pp. 92-112. ISSN 13506307.

[21] ČUBOŇOVÁ, N., (2013). Postprocessing of CL Data in CAD/CAM system Edgecam using the Constructor of postprocessors. In: Manufacturing Technology. Vol. 13, No. 2, pp. 158 - 164. ISSN 12132489 ..

[22] NOVÁK, P., MEŠKO, J., ŽMINDÁK, M. (2013). Finite Element Implementation of Multi-Pass Fillet Weld with Phase Changes. In: Manufacturing Technology. Vol. 13, No. 1. pp. 79 - 85. ISSN 12132489.

[23] Steel Wire Ropes/Wires, In: AVIMAR [Online]. Available:< http://avimarltd.tripod.com/swropes.html >, [Accessed: 28-December-2015 ]

[24] MOLNAR, V., BOROSKA, J., DECMANOVA, J. (2010). Mechanical properties of steel rope wires -- quality test assurance. In: Acta Montanistica Slovaca. Vol. 15, No. 1 Spec. Issue. pp. 23 - 30. ISSN 1335-1788

[25] DANESHJO, N., KORBA, P., VARGOVÁ, R., TAHZIB, B. (2013). Application of 3D modeling and simulation using modular components. In: Applied Mechanics and Materials. Vol. 389, pp. 957-962, ISSN 1660-9336

[26] STEJSKAL, T., SVETLÍK, J. (2012). Failure rate for repaired and not repaired object. In: International journal of engineering. Vol. 10, no. 3. ISSN 1584-2673 